\title{
The Influence of pH of Water and Chemical Composition on the Durability of Different Rocks from the Qom Formation, East and Northeast of Hamedan, Iran
}

\author{
*Ghobadi M.H., Kapelehe M.; \\ Deparment of Geology, Bu-Ali Sina University, Hamedan \\ Received: 26 Aug 2013 \\ Revised: 30 Dec 2014
}

\begin{abstract}
Durability is a significant parameter in engineering geology and it shows the extent of the degradability of rocks as the result of mechanical and chemical breakdowns. This phenomenon is closely linked to the composition, porosity and texture of rocks. To understand the relationship between the chemical composition of rocks and their durability the mineralogical properties of the rocks along with durability tests under both acidic and alkaline $\mathrm{pH}$ environments were determined. Five samples of limestone and three samples of marl were analyzed. The results revealed that rocks containing high levels of $\mathrm{CaCo}_{3}$ were affected in the acidic conditions while rocks containing high levels of $\mathrm{SiO}_{2}$ were not affected by variance in the $\mathrm{pH}$ of the environment. These second groups of rocks were more dependent on the texture of their constituent minerals.
\end{abstract}

Keywords: Slake durability index, pH, Mineralogical properties, Chemical composition, Texture, Qom formation.

${ }^{*}$ Corresponding author amirghobadi@yahoo.com 


\section{Introduction}

Environmental Geology is an emerging field which aims to understand the relationship between the behavior of different rock masses under varying environmental conditions (Ghobadi, 2000, 2011, 2014, Manassero \& Deangeli, 2002). Durability is an important engineering parameter and this is especially true for weak rocks (Franklin \& Chandra, 1972, Dick \& Shakoor, 1995, Gokceoglu et al., 2000). This important parameter is defined as the degradability of rocks as a result of chemical and mechanical breakdowns such as exfoliation, hydration, solution, oxidation, and abrasion. The mineral composition of rocks and their texture are closely associated with the concept of durability (Beavis, 1985, Ghobadi, $2002 \&$ 2006). Also, another important factor in the process of the mechanical breakdown of rocks is the $\mathrm{pH}$ of the fluid in which they are exposed to.

A large number of studies have been carried out to show how different environmental conditions affect the mechanical properties of different rocks such as quartzite, granite, sandstone, rock salt, dolomite, and limestone (Colbach and Wild, 1965, Ghobadi 2005, Jamshid et al, 2013). In addition, it is now clear that the mineral composition of rocks along with their texture such as crystal interlocking, surface roughness, effective porosity, crystal perimeter length, crystal area, as well as crystal shape and crystal side have a significant effect on the durability of rocks (Papadopoulos, et al., 1994, Dhakal et al. 2002, Yilmaz \& Karacan, 2005, Kolay \& Kayabali, 2006, Gupta \& Ahmed, 
2007). Singh et al., (2006) demonstrated that at pH 7 marble shows its highest strength characteristics. He also demonstrated that this strength is higher in alkaline conditions compared to acidic environments. In his 2005 paper, Singh et al. examined the durability index of shale in exposure to acidic water under laboratory conditions and he predicted the durability of shaly rocks using an artificial neural network system and a neuro-fuzzy system. Also, Sunil et al., (2006) examined the engineering properties and chemical characteristics of soil under the effect of different $\mathrm{pH}$ solutions.

In this article, the durability of different rocks collected from the Qom formation located in east and northeast of Hamedan in water possessing different $\mathrm{pH}$ levels has been investigated.

\section{Material and Methods}

The samples were collected from east and northeast of Hamedan located in West of Iran (Figure. 1). The rocks belong to the sedimentary sequence of the Qom Formation and they form a part of the syncline. Five samples of limestone and three samples of marl were analyzed. The sampling locations are shown in Figure. 2.

The samples were selected on the basis of their homogeneity in visible macroscopic characteristics such as texture and color. Each block size was about $30 \mathrm{~cm} \times 20 \mathrm{~cm} \times 15 \mathrm{~cm}$. Prior to performing the durability test mineralogical, textual, and physical properties of samples such as the specific gravity $\left(G_{s}\right)$, the water absorption $\left(\omega_{\alpha}\right)$, the porosity $(n)$, 
the saturated unit weight $\left(\gamma_{\text {sat }}\right)$, and the dry unit weight $\left(\gamma_{d}\right)$ were determined (Table 1).

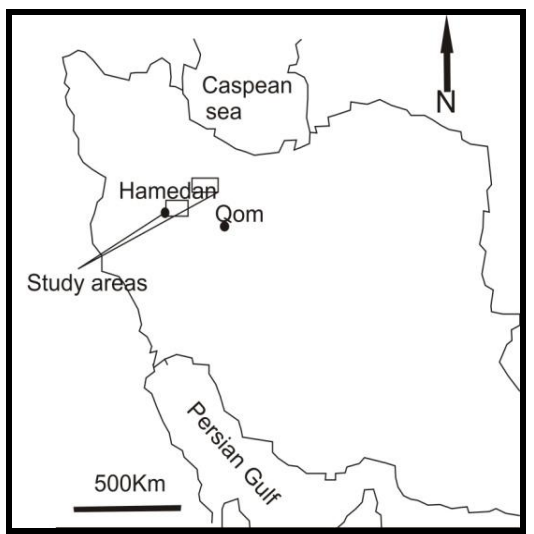

Figure. 1. Location map of the study area.
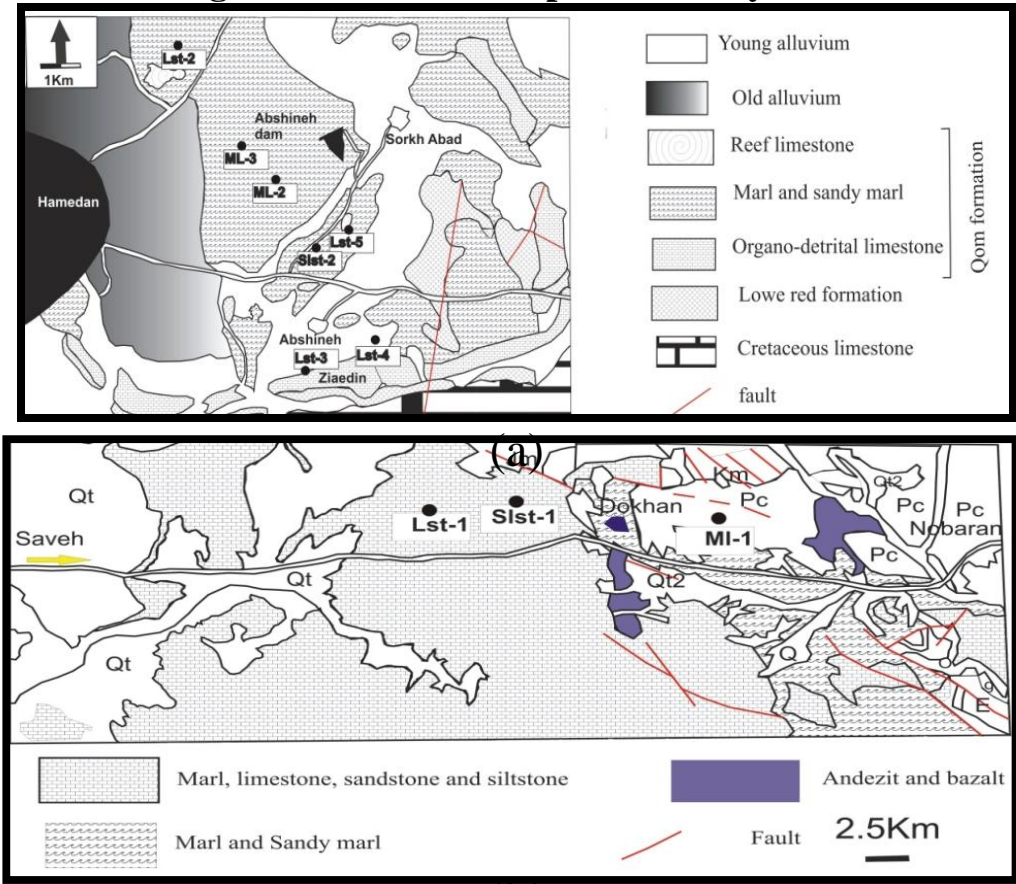

(b)

Figure. 2. Geological map of the study area. The sampling sites are marked in the Figures (a, b) 
Textual features and chemical compositions of the samples were examined by optical microscopy, X-ray fluorescence (XRF), and the Calcimeter test. Standard testing procedures were used to determine the above cited physical properties. Different $\mathrm{pH}$ levels were prepared by adding 1 molar $\mathrm{HCI}$ for the acidic solution and 1 Molar $\mathrm{NaOH}$ for basic solution in distilled water.

\section{Mineralogical properties}

The classification of Dunham (1962) divides limestone on the basis of texture into: grainstone, grain without matrix, packestone, grain in contact with matrix, wackestone, coarse grains floating in a matrix, and mudstone; micrite with a few grains. The mineral constituents along with its texture greatly influence the engineering properties of the rocks. These were studied in thin sections using optical microscopy.

Microscopic studies on the limestone revealed that Lst-1 according to the classification of Dunham is packstone; grain in contact with matrix (this could be a biomicrite). This sample has algae allochms, bryozoa, foraminifera and echinodermata. The average size of the grain varies between 0.06 to $0.43 \mathrm{~mm}$. It possess a number of pores in variable shapes and sizes. It has a porosity of $11.90 \%$. Vuggy porosity is visible and cracks are filled with recrystallized calcite (Figure.3a).

Lst-2 is coarse grained limestone and has a low porosity which according to Dunham's classification is a packstone; grain in contact 
with matrix (this could be biosparite). It has foraminifera allochms, algae, corals, echinodermata, bivalve shell, quartz, plagioclase, volcanic and clastic small pieces. Intercrystal porosity is visible. Due to cementation of pore the space porosity is low (Figure,3). It has a porosity of $1.52 \%$. The average size of the grain varies between 0.06 to $0.43 \mathrm{~mm}$. The grains are angular to sub-angular and are arranged in an interlocking fashion (Figure.3b).

Lst-3 is fine grained limestone. This sample according to Dunham's classification is wackestone (this could be biosparite). It has foraminifera allochms, echinodermata, bivalve fragments and bryozoa pieces (Figure.3c). In this sample, compared to other limestones, Allochms are more crashed. It has a porosity of $5.20 \%$. The average size of the grain varies between 0.03 to $0.39 \mathrm{~mm}$.

Lst-4 is coarse grained and according to Dunham's classification is a grainstone (this could be biosparite). It has echinodermata allochms, bivalve, foraminifera, coral, quartz and plagioclase (Figure.3d). Intercrystal porosity is visible. Having sub-angular to sub rounded grains, it is arranged in an interlocking pattern. It has a porosity of $2.20 \%$. The average size of the grain varies between 0.06 to $0.43 \mathrm{~mm}$.

Lst-5 is calcarenite. This sample has echinodermata, red algae, gastropods pieces, quartz, feldspar, volcanic pieces and iron oxides, fine to medium grained limestone. Most grains are between $2 \mathrm{~mm}$ and $62 \mu \mathrm{m}$. The fractures are filled with recrystallized calcite with an average grain size of about $0.75 \mathrm{~mm}$ giving the impression of a well- 
The Influence of $\mathrm{pH}$ of Water and Chemical Composition on the Durability of Different Rocks... $\mathbf{3 7 0 5}$

developed comb shape structure (Figure.3e). It has a porosity of $6.02 \%$.

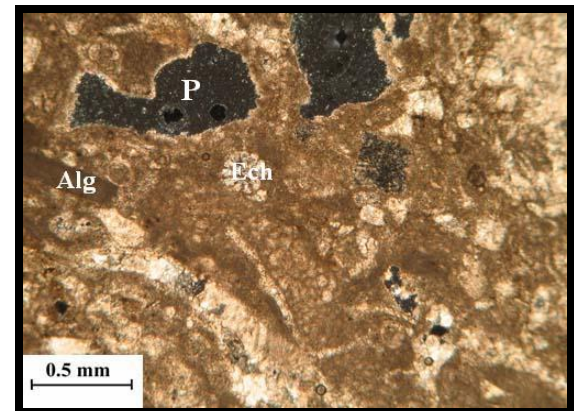

(a) Lst-1

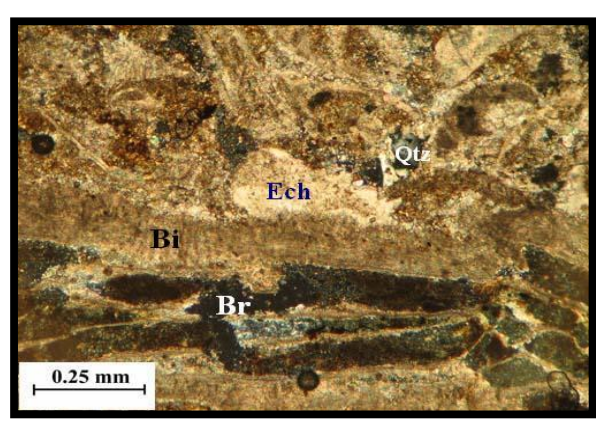

(c) Lst3

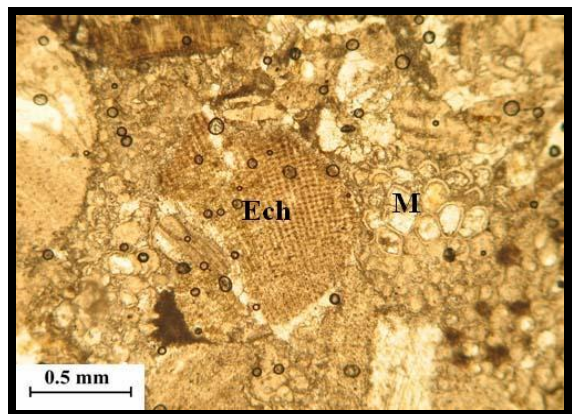

(b) Lst-2

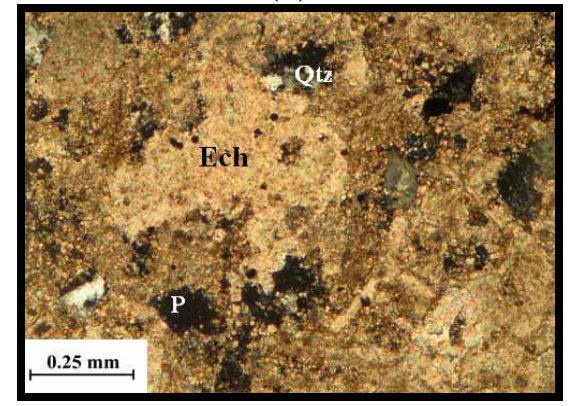

(d)Lst-4

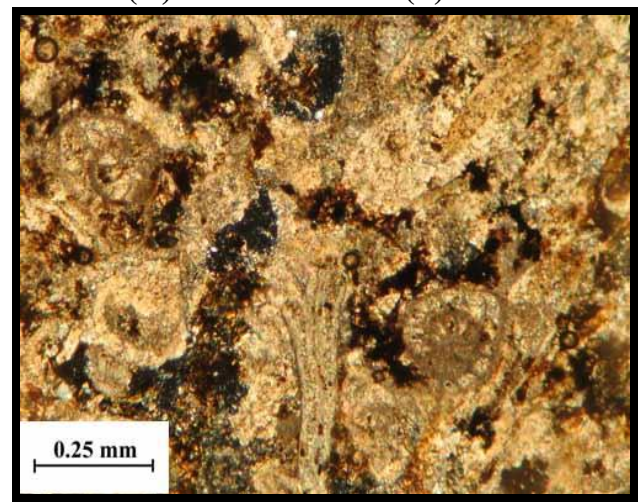

(e) Lst-5

Figure. 3: Photomicrographs of the thin sections showing (a) Lst-1, (b) Lst-2, (c) Lst-3, (d) Lst-4, and (e) Lst-5. X-ray fluoreseence (XRF) 
To analyze the chemical composition of limestones semi quantitatively, XRF on the whole rock powder was carried out (Table 2). The analyses revealed that Lst-1 consist of $53.36 \% \mathrm{CaO}$ and $1.50 \% \mathrm{SiO}_{2}$. Lst-2 consist of $55.88 \% \mathrm{CaO}$ and $8.54 \mathrm{SiO}_{2}$. Lst-3 consist of $42.05 \% \mathrm{CaO}$ and $6.88 \% \mathrm{SiO}_{2}$. Lst-4 consist of $34.95 \%$ $\mathrm{CaO}$ and $14.38 \mathrm{SiO}_{2}$. Lst-5 consist of $4.55 \% \mathrm{CaO}$ and $52.18 \% \mathrm{SiO}_{2}$

To analyze the chemical composition of Marl semi quantitatively, $\mathrm{XRF}$ on the whole rock powder was carried out (Table 3). Marl $_{1}$ comprises $31.06 \% \mathrm{CaO}$ and $24.5 \% \mathrm{SiO}_{2} . \mathrm{Marl}_{2}$ comprises $18.20 \%$ $\mathrm{CaO}$ and $43.34 \% \mathrm{SiO}_{2} . \mathrm{Marl}_{3}$ comprises $27.2 \mathrm{O} \% \mathrm{CaO}$ and $28.94 \%$ $\mathrm{SiO}_{2}$.

\section{Calcimeter test}

The calcium carbonate content of rock (ASTM Procedure D4373, 1990) was determined by treating a $1 \mathrm{~g}$ dried rock powder with $\mathrm{HCl}$ in reactor cell. The resulting pressure increase was then measured and was compared to the calibration curve to determine the total weight of $\mathrm{CaCO}_{3}$ in the test sample. The below equation was used to calculate the percentage of $\mathrm{CaCO}_{3}$.

$$
\% \mathrm{CaCO}_{3}=\frac{(\text { Pressure } \mathrm{Re} \text { ading }, P S I)(100)}{(\text { SampleWeight })(\text { AverageSlope })}
$$

For values of average slope a Calibration Curve is required.

The percentage of $\mathrm{CaCO}_{3}$ of limestone and Marl are shown in Table 4. Average $\mathrm{CaCO}_{3} \%$ of limestone (Ls-1-5) are (87.33), (74.66), 
(78.33), (65.30) and (58.83) respectively, and average $\mathrm{CaCO}_{3} \%$ of Marl(1-3) are (54.08), (18.67) and (40.25).

\section{Index properties of rocks}

The specific gravity $\left(\mathrm{G}_{\mathrm{s}}\right)$, the water absorption $\left(\omega_{\alpha}\right)$, the porosity $(n)$, the dry density $\left(\gamma_{d}\right)$, and the saturated density $\left(\gamma_{\text {sat }}\right)$ of the rocks were determined in accordance with the ISMR (1981) standard procedure (Table 1). The evaluation of the basic engineering properties was carried out on $25 \mathrm{~mm}$ diameter cores of all rock types. The cores were washed and oven dried for 24 hours at $110 C^{\circ}$ and dipped into water. These samples were weighed at fixed time intervals to determine the saturated density, the water absorption, and the porosity. The cores dipped into water were weighed until a constant measure of weight was recorded. Dry and saturated density was defined as the ratio of dry and saturated mass to their volume. Porosity was calculated by using the water saturation method whereas the specific gravity was calculated by the water displacement method (Brown, 1981).

\section{Slake Durability Test}

The potential deterioration of the durability of rocks caused by the climate was predicted by the slake durability Test (Franklin \& Chandra, 1972). The degradability of gypsum and anhydrate (Bell 1994, Papadopoulos et al., 1994, Kayabali et al., 2006), marble (Singh 
et al., 2006), and laterite (Sunil et al., 2006) in different $\mathrm{pH}$ environments were successfully determined using the above noted test.

In the present article, the Slake Durability Test was done according to ASTM (D 4644-87, 1998). The test was carried out on five samples of limestone and three samples of marl collected from the Qom formation. This was to understand the effect of different $\mathrm{pH}$ environments on the deterioration of the collected rocks. Ten rock pieces for each sample weighing between 40 to 60 gm were taken and the edges of these pieces were made blunt using a chisel. The drum used to rotate the rock pieces was half immersed in a slaking fluid with a temperature of about $20 C^{\circ}$ and the rock pieces were rotated for ten minutes at $20 \mathrm{rpm}$. The drum was made of a sieve mesh of 2 $\mathrm{mm}$ so that the slacking product from the rock could pass through the sieve into the water. The retained rock pieces were oven dried at $110 \mathrm{C}^{\circ}$ for $24 \mathrm{~h}$, and next they were cooled and weighed. All rock samples were tested at $\mathrm{pH}$ environments of 2, 4, 6, 8, 10, and 12. Each rock type went through five test cycles. The percentage ratio of the final and initial dry weight of rocks tested in the drum was recorded as the slake durability Index (SDI) for each sample. A lower SDI for a given sample shows that it is more likely to degrade under a given set of environmental conditions. According to Johnson and Degraff (1988), rocks can be classified into six groups on the basis of their 
durability to environmental conditions (Table 5). The results are presented in Figures. 4 and 5.

\section{Evaluation of results and discussion}

There exists a relationship between the slake durability index (SDI) of different rocks and the $\mathrm{pH}$ environment in which they are exposed to (Figures. $4 \& 5$ ). The results show that higher amounts of $\mathrm{CaCO}_{3}$ in rocks lead to higher slaking at lower $\mathrm{pH}$ levels (Figures. $4 \& 5$ ). This is due to the high susceptibility of $\mathrm{CaCO}_{3}$ to acidic agents. The dissolution of calcium carbonate increases at lower $\mathrm{pH}$ levels due to the fact that the acid is more able to attack the free charged particle that binds the carbonate $\left(\mathrm{CO}_{3}\right)$ (Singh et al., 2006). The nature of the acid affects the speed of the deterioration. The SDI for limestone in the first $\left(\mathrm{I}_{\mathrm{d} 1}\right)$ and second $\left(\mathrm{I}_{\mathrm{d} 2}\right)$ cycles tested under different $\mathrm{pH}$ environments appears to be highly related to the texture of the rock rather than the ionic strength of the testing solution. The lowest average SDI (97.97\%) tested under different $\mathrm{pH}$ levels belongs to Lst1 for the second cycle $\left(I_{d 2}\right)$ which is weathered and porous (Figure. 6). On the other hand, the highest average SDI (99.04\%) is for Lst-5 for the second cycle $\left(\mathrm{I}_{\mathrm{d} 2}\right)$ which is coarse grained having sub-angular grains arranged in an interlocking fashion (Figure. 6). The average SDI tested under different $\mathrm{pH}$ levels for Lst-2, Lst-3, and Lst-4 for the second cycle $\left(I_{d 2}\right)$ is $99.08 \%, 99.04 \%$, and $99.02 \%$ respectively which shows that the limestone possesses high to very high durability 
(Figure. $6 \&$ Table 6). The results indicate that coarse grain limestone has a higher durability index compared to fine grained limestone in all $\mathrm{pH}$ environments. This is probably due to higher surface exposure of the fine grained variant to the outside agent which in this case is the testing fluid. The three marl samples tested for determining the SDI also show a similar pattern. Like limestone, the marl-1 sample which was mainly comprised of $54.08 \% \mathrm{CaCO}_{3}$ and $24 \% \mathrm{SiO}_{2}$ was more susceptible to degradation at lower $\mathrm{pH}$ levels (Figure. 5f \& Figure. 7). Marl-2 which was mainly comprised of $18.68 \% \mathrm{CaCO}_{3}$ and $43.34 \%$ $\mathrm{SiO}_{2}$ had some slaking independent of the environmental $\mathrm{pH}$ levels (Figure. 5g \& Figure. 7).

\section{Conclusion}

The degradability of samples of limestone and marl collected from the Qom formation at different $\mathrm{pH}$ levels was the focus of this paper. The results show that the degradability of rocks is highly dependent on their mineral constituents, chemical composition and texture. Rocks containing large amounts of $\mathrm{CaCO}_{3}$ (more than 65\%), in our case limestone and marl, are more degradable to acidic solutions (Figure. $4 \& 5$ ). This higher index is related to the chemical reaction of calcium carbonate $\left(\mathrm{CaCO}_{3}\right)$ with the acidic solution which results in the reduction of bond strength between the different particles. Also, results show that fine grained limestone has a higher degradation index compared to its coarse grained variant. Since many developmental activities are being planned in the Qom formation area, 
the results of this study can be beneficial to the geotechnical engineers.

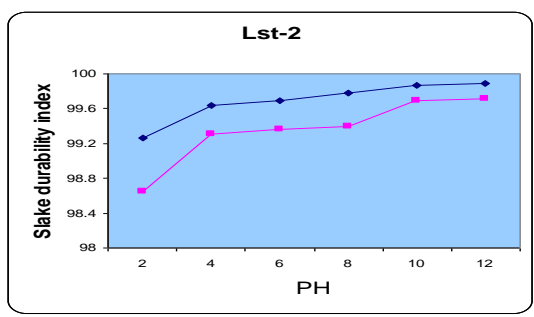

(b)

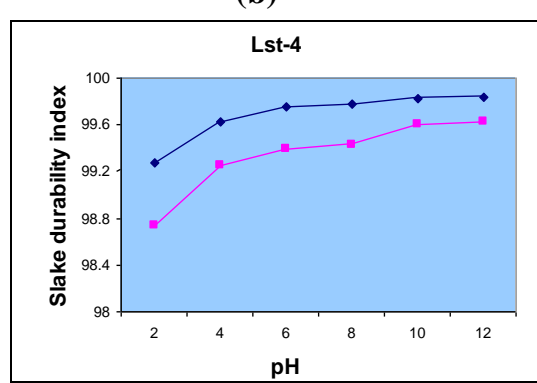

(d)

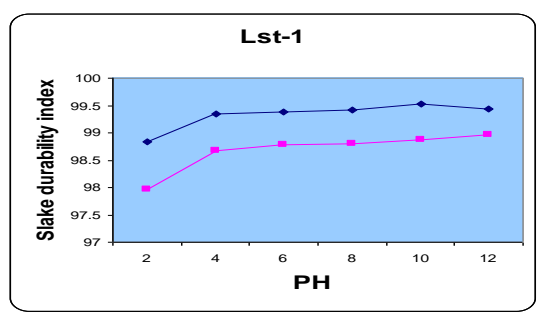

(a)

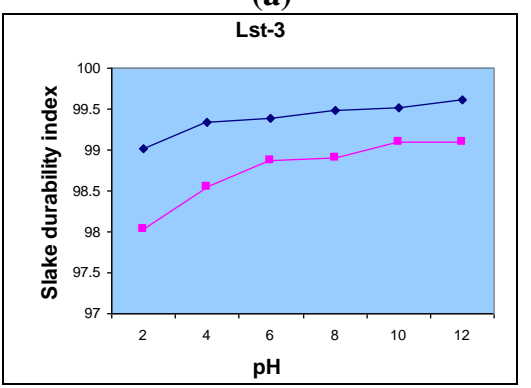

(c)

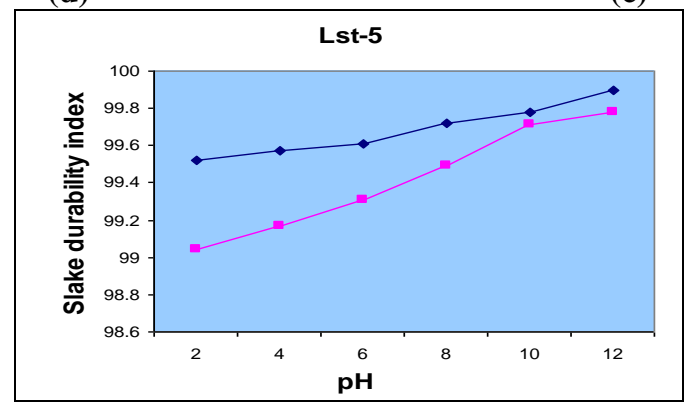

(e)

Figure.4. The results of the first and second cycle slake durability tests conducted on five samples (Lst 1-5) of limestone. (Square indicates the result of the first cycle, and the triangle indicates the second cycle). 


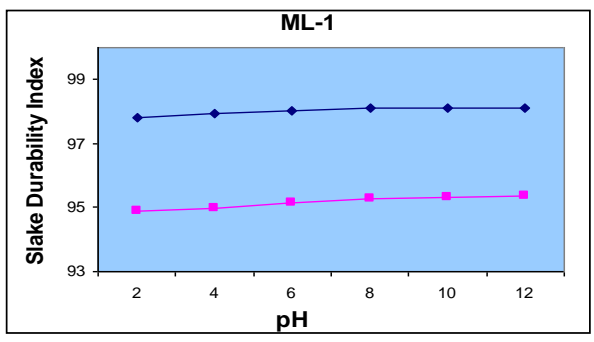

(f)

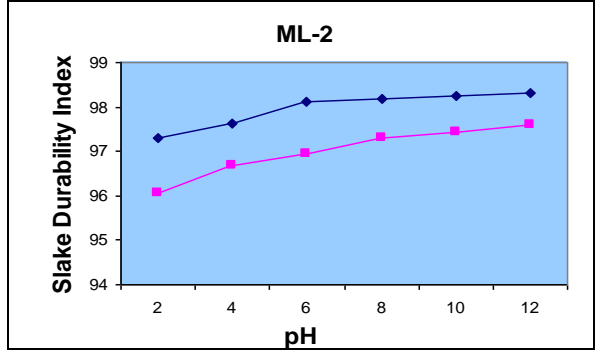

(g)

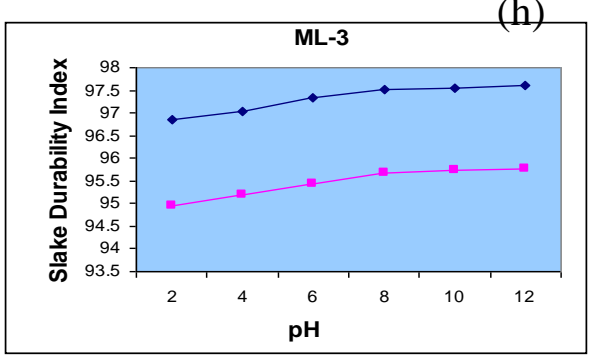

ig.5. The results of the first and second cycle slake durability tests conducted on three samples (ML 1-3). (Square indicates the result of the first cycle, and the triangle indicates the second cycle).

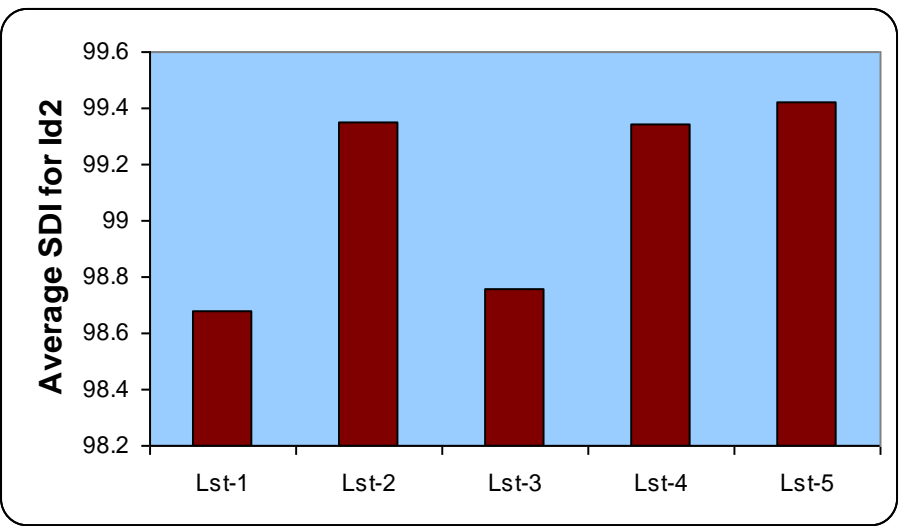

Figure.6. Average slake durability index for the second cycle $\left(I d_{2}\right)$ of various limestones when tested under different $\mathrm{pH}$ conditions. 


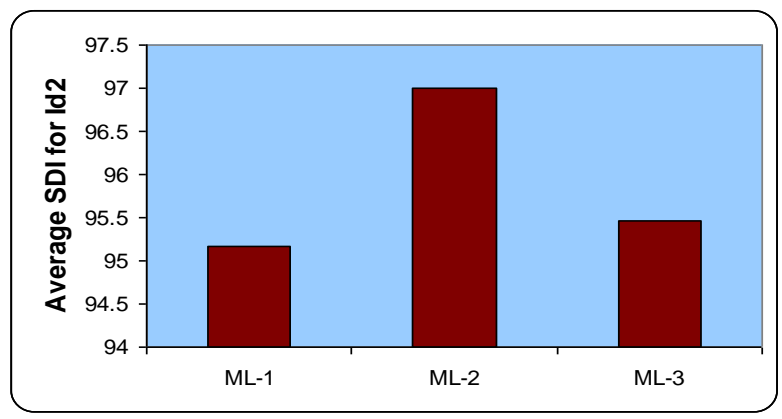

Figure.7. Average slake durability index for the second cycle $\left(I d_{2}\right)$ of various marls when tested under different $\mathrm{pH}$ conditions.

Table 1. Physical properties of different rocks of the Qom formation.

\begin{tabular}{|c|c|c|c|c|c|c|}
\hline \multirow{4}{*}{ Rock type } & $\begin{array}{c}\text { Sample } \\
\text { no. }\end{array}$ & $\left(\omega_{a}\right)$ & $(n)$ & $\left(G_{s}\right)$ & $\left(\gamma_{d}\right) \mathrm{g} / \mathrm{cm}^{3}$ & $\left(\gamma_{\text {sat }}\right) \mathrm{g} / \mathrm{cm}^{3}$ \\
\hline \multirow{4}{*}{ Limestone } & Lst-1 & 0.132 & 11.66 & 2.55 & 2.25 & 2.37 \\
\cline { 2 - 7 } & Lst-2 & 0.015 & 1.52 & 2.51 & 2.47 & 2.49 \\
\cline { 2 - 7 } & Lst-3 & 0.055 & 5.20 & 2.51 & 2.38 & 2.43 \\
\cline { 2 - 7 } & Lst-4 & 0.022 & 2.20 & 2.59 & 2.53 & 2.55 \\
\cline { 2 - 7 } & Lst-5 & 0.064 & 6.02 & 2.63 & 2.47 & 2.53 \\
\hline \multirow{3}{*}{ Marl } & ML-1 & 0.342 & 8.33 & 2.62 & 2.40 & 2.48 \\
\cline { 2 - 7 } & ML-2 & 0.542 & 12.80 & 2.69 & 2.34 & 2.47 \\
\cline { 2 - 7 } & ML-3 & 0.641 & 14.35 & 2.65 & 2.27 & 2.41 \\
\hline
\end{tabular}

Table 2. The results of the XRF tests for limestone samples.

\begin{tabular}{|c|c|c|c|c|c|}
\hline Sample No. & Lst-1 & Lst-2 & Lst-3 & Lst-4 & Lst-5 \\
\hline$\% \mathrm{SiO}_{2}$ & 1.50 & 8.54 & 6.88 & 14.38 & 52.18 \\
\hline$\% \mathrm{Al}_{2} \mathrm{O}_{3}$ & 0.10 & 2.01 & 1.82 & 4.24 & 1.38 \\
\hline$\% \mathrm{Na}_{2} \mathrm{O}$ & 0.01 & 0.13 & 0.12 & 0.14 & 0.02 \\
\hline$\% \mathrm{MgO}$ & 0.93 & 1.89 & 5.66 & 6.00 & 0.11 \\
\hline$\% \mathrm{~K}_{2} \mathrm{O}$ & 0.08 & 0.43 & 0.41 & 0.61 & 0.41 \\
\hline$\% \mathrm{TiO}_{2}$ & 0.13 & 0.19 & 0.19 & 0.23 & 0.17 \\
\hline$\% \mathrm{MnO}$ & 0.03 & 0.02 & 0.04 & 0.05 & 0.04 \\
\hline$\% \mathrm{CaO}$ & 53.36 & 55.88 & 42.05 & 34.95 & 4.55 \\
\hline
\end{tabular}




\begin{tabular}{|c|c|c|c|c|c|}
\hline Sample No. & Lst-1 & Lst-2 & Lst-3 & Lst-4 & Lst-5 \\
\hline$\% \mathrm{P}_{2} \mathrm{O}_{5}$ & 0.06 & 0.09 & 0.11 & 0.12 & 0.02 \\
\hline$\% \mathrm{Fe}_{2} \mathrm{O}_{3}$ & 0.84 & 1.56 & 2.04 & 2.41 & 2.42 \\
\hline$\% \mathrm{SO}_{3}$ & 0.02 & 0.07 & 0.85 & 0.12 & 0.00 \\
\hline$\% \mathrm{LI}$ & 42.96 & 39.07 & 39.68 & 36.62 & 38.63 \\
\hline
\end{tabular}

Table 3. The results of the XRF tests for marl samples

\begin{tabular}{|c|c|c|c|}
\hline Sample No. & ML-1 & ML-2 & ML-3 \\
\hline$\% \mathrm{SiO}_{2}$ & 24.50 & 43.34 & 28.94 \\
\hline$\% \mathrm{Al}_{2} \mathrm{O}_{3}$ & 7.67 & 9.33 & 8.85 \\
\hline$\% \mathrm{Na}_{2} \mathrm{O}$ & 0.38 & 0.79 & 0.41 \\
\hline$\% \mathrm{MgO}_{\% \mathrm{~K}_{2} \mathrm{O}}$ & 1.55 & 2.77 & 1.93 \\
\hline$\% \mathrm{TiO}_{2}$ & 1.48 & 1.91 & 1.70 \\
\hline$\% \mathrm{MnO}$ & 0.39 & 0.57 & 0.40 \\
\hline$\% \mathrm{CaO}$ & 0.18 & 0.07 & 0.14 \\
\hline$\% \mathrm{P}_{2} \mathrm{O}_{5}$ & 31.06 & 18.20 & 27.20 \\
\hline$\% \mathrm{SO}_{3}$ & 0.15 & 0.12 & 0.10 \\
\hline$\% \mathrm{LOI}_{3}$ & 3.56 & 4.86 & 3.48 \\
\hline
\end{tabular}

Table 4. The results of the Calcimeter tests for all samples.

\begin{tabular}{|c|c|c|c|c|}
\hline \multirow{2}{*}{ Sample No. } & \multicolumn{4}{|c|}{$\mathrm{CaCO}_{3} \%$} \\
\cline { 2 - 5 } & Sample 1 & Sample 2 & Sample 3 & Average \\
\hline ML-1 & 54.00 & 54.00 & 54.25 & 54.08 \\
\hline ML-2 & 18.75 & 18.50 & 18.75 & 18.67 \\
\hline ML-3 & 40.00 & 40.50 & 40.25 & 40.25 \\
\hline Lst-1 & 91.80 & 84.00 & 86.19 & 87.33 \\
\hline Lst-2 & 71.70 & 77.00 & 75.28 & 74.66 \\
\hline Lst-3 & 75.00 & 79.00 & 80.99 & 78.33 \\
\hline Lst-4 & 63.00 & 64.50 & 68.40 & 65.30 \\
\hline Lst-5 & 59.20 & 57.00 & 60.29 & 58.83 \\
\hline
\end{tabular}


The Influence of $\mathrm{pH}$ of Water and Chemical Composition on the Durability of Different Rocks... $\mathbf{3 7 1 5}$

Table 5. Two-cycle slake durability classification of rocks (Johnson and DeGraff, 1988)

\begin{tabular}{|c|c|c|}
\hline Cycle 2 (\% Retained) & Cycle 1 (\% Retained) & Durability \\
\hline$<30$ & $<60$ & Very low \\
\hline $30-60$ & $60-85$ & Low \\
\hline $60-85$ & $85-95$ & Medium \\
\hline $85-95$ & $95-98$ & Medium high \\
\hline $95-98$ & $98-99$ & High \\
\hline$>98$ & $>99$ & Very high \\
\hline
\end{tabular}

Table 6. The results of the first and second cycle slake durability tests for limestones

\begin{tabular}{|c|c|c|c|c|c|c|c|c|}
\hline \multicolumn{3}{|c}{ Lst-1 } & \multicolumn{3}{c|}{ Lst-2 } & \multicolumn{3}{c|}{ Lst-3 } \\
\hline $\mathrm{pH}$ & $\mathrm{Id} 1$ & $\mathrm{Id} 2$ & $\mathrm{pH}$ & $\mathrm{Id} 1$ & $\mathrm{Id} 2$ & $\mathrm{pH}$ & $\mathrm{Id} 1$ & $\mathrm{Id} 2$ \\
\hline 2 & $98 / 83$ & $97 / 97$ & 2 & $99 / 26$ & $98 / 65$ & 2 & $99 / 02$ & $98 / 04$ \\
\hline 4 & $99 / 34$ & $98 / 68$ & 4 & $99 / 64$ & $99 / 31$ & 4 & $99 / 34$ & $98 / 55$ \\
\hline 6 & $99 / 39$ & $98 / 78$ & 6 & $99 / 69$ & $99 / 36$ & 6 & $99 / 39$ & $98 / 87$ \\
\hline 8 & $99 / 42$ & $98 / 8$ & 8 & $99 / 78$ & $99 / 4$ & 8 & $99 / 48$ & $98 / 91$ \\
\hline 10 & $99 / 52$ & $98 / 87$ & 10 & $99 / 87$ & $99 / 69$ & 10 & $99 / 52$ & $99 / 09$ \\
\hline 12 & $99 / 44$ & $98 / 96$ & 12 & $99 / 89$ & $99 / 71$ & 12 & $99 / 62$ & $99 / 1$ \\
\hline
\end{tabular}

\begin{tabular}{|c|c|c|c|c|c|}
\hline \multicolumn{2}{|c|}{ Lst-4 } & \multicolumn{3}{c|}{ Lst-5 } \\
\hline $\mathrm{pH}$ & $\mathrm{Id} 1$ & $\mathrm{Id} 2$ & $\mathrm{pH}$ & $\mathrm{Id} 1$ & $\mathrm{Id} 2$ \\
\hline 2 & $99 / 27$ & $98 / 74$ & 2 & $99 / 52$ & $99 / 04$ \\
\hline 4 & $99 / 62$ & $99 / 25$ & 4 & $99 / 57$ & $99 / 17$ \\
\hline 6 & $99 / 75$ & $99 / 39$ & 6 & $99 / 61$ & $99 / 31$ \\
\hline 8 & $99 / 78$ & $99 / 43$ & 8 & $99 / 72$ & $99 / 49$ \\
\hline 10 & $99 / 82$ & $99 / 6$ & 10 & $99 / 78$ & $99 / 71$ \\
\hline 12 & $99 / 84$ & $99 / 63$ & 12 & $99 / 9$ & $99 / 78$ \\
\hline
\end{tabular}

Table 7. The results of the first and second cycle slake durability tests for Marls

\begin{tabular}{|r|r|r|r|r|r|r|r|r|}
\hline \multicolumn{3}{|c|}{ ML-1 } & \multicolumn{3}{|c|}{ ML-2 } & \multicolumn{3}{|c|}{ ML-3 } \\
\hline $\mathrm{pH}$ & $\mathrm{Id} 1$ & $\mathrm{Id} 2$ & $\mathrm{pH}$ & $\mathrm{Id} 1$ & $\mathrm{Id} 2$ & $\mathrm{pH}$ & $\mathrm{Id} 1$ & $\mathrm{Id} 2$ \\
\hline 2 & $97 / 81$ & $94 / 87$ & 2 & $97 / 29$ & $96 / 05$ & 2 & $96 / 85$ & $94 / 96$ \\
\hline 4 & $97 / 93$ & $94 / 98$ & 4 & $97 / 63$ & $96 / 67$ & 4 & $97 / 02$ & $95 / 19$ \\
\hline 6 & $98 / 02$ & $95 / 14$ & 6 & $98 / 11$ & $96 / 94$ & 6 & $97 / 33$ & $95 / 43$ \\
\hline 8 & $98 / 11$ & $95 / 27$ & 8 & $98 / 18$ & $97 / 29$ & 8 & $97 / 51$ & $95 / 67$ \\
\hline 10 & $98 / 13$ & $95 / 32$ & 10 & $98 / 24$ & $97 / 42$ & 10 & $97 / 56$ & $95 / 72$ \\
\hline 12 & $98 / 12$ & $95 / 37$ & 12 & $98 / 32$ & $97 / 61$ & 12 & $97 / 62$ & $95 / 77$ \\
\hline
\end{tabular}

Acknowledgements 
All the required tests have been carried out in the engineering geological laboratory of the Bu-Ali Sina University, Hamedan, Iran.

\section{References}

1. ASTM (D 4373), 1990. Standard Test Method for Calcium Carbonate Content in Soils.

2. ASTM, "Standard test method for Slake Durability of shales and similar weak rocks", Annual Book of Standards (1998) (D 4644-87).

3. Beavis F.C., "Engineering Geology. Blackwell", Melbourn (1985).

4. Bell F.G., "A survey of engineering properties of some anhydrite and gypsum from the North and Midlands of England", Engineering geology 38 , (1994) 1-23.

5. Brown E.T., "Rock characterization, testing and monitoring", ISRM suggested methods, 211. Pergamon Press, Oxford (1981).

6. Colbach P.S.B., Wild B.I., "The influence of moisture content on compressive strength of rocks", $3^{\text {rd }}$ Canadian rock mechanics symposium, Toronto (1965) 63-65.

7. Dhakal G., Yoneda T., Kato M., Kaneko K., "Slake durability and mineralogical properties of some pyroclastic and sedimentary rocks", Engineering Geology 65 (2002) 31-45.

8. Dick J.A., Shakour A., "Characterizing durability of mud rocks for slope stability purposes", Engineering Geology 10 (1995) 121-130.

9. Franklin J.A., Chandra A., "The slake durability test", International Journal of Rock Mechanics and Mining Sciences 9 (1972) 325-341.

10. Ghobadi M.H. "Petrology, Weathering and Long-Term stability slopes", $8^{\text {th }}$ Inter. IAEG Congress, Canada (2000). 
11. Ghobadi M.H. "Relationship between static and dynamic durability with mineralogy", First National Conference on Rock mechanics, Tarbiate modarres university, Tehran, Iran (In Persian) (2002).

12. Ghobadi M.H., "Assessment of solubility of Asmari limestone in Karun 1 damsite, Iran", ICOLD, 73th Annual Meeting of ICOLD, Tehran, Iran (2005).

13. Ghobadi M.H., Karami R., "The importance of physical and chemical properties of carbonate rocks in karst engineering geology", 4th National Conference on Engineering Geology and the Environment. Tarbiate moderres university, Tehran, Iran (In Persian) (2006).

14. Ghobadi M.H., Momeni A.A., "Assessment of granitic rocks degradability susceptiveto acid solutions in urban area", Environ Earth Sci. DOI 10.1007/s12665-010-0895-6. 64 (2011) 753-760.

15. Ghobadi M.H., Mousavi S., "The effect of $\mathrm{pH}$ and salty solutions on durabilityof sandstones of the Aghajari Formation in Khouzestan province, southwest of Iran", Arab J Geosci. DOI 10.1007/s12517-0120741-0 (2014).

16. Gokceoglu C., Ulusay R., Sonmez H., "Factor affecting the durability of selected weak and clay bearing rocks from Turkey, with particular emphasis on the influence of number of drying and wetting cycles", Engineering Geology 57 (2000) 215-237.

17. Gupta V., Ahmed I., "The effect of $\mathrm{pH}$ of water mineralogical properties on the slake durability (degradability) of different rocks from the Lesser Himalaya, India", Engineering Geology 95 (2007) 79-87. 
18. Jamshidi A., Nikudel M.R., Khamehchiyan M., "Predicting the longterm durability of building stones against freeze-thaw using a decay function model", Cold Regions Science and Technology 92 (2013) 29-36.

19. Johnson R.B., DeGraff J.V., "Principles of Engineering Geology", Wiley, New York (1988).

20. Kayabali K., Beyaz T., Kolay E., "The effect of the pH of the testing liquid on the slake durability of gypsum", Bulletin Engineering Geology and the Environment 65 (2006) 65-71.

21. Kolay E., Kayabali K., "Investigation of effect of aggregate shape and surface roughness on the slake durability index using fractal dimension approach", Engineering geology 86 (2006) 271-284.

22. Papadopoulos Z., Kolaiti E., Mourtzas N., "The effect of crystal size on geotechnical properties of Neogene gypsum in cret", Quaterly Journal of Engineering Geology27 (1994) 267-273.

23. Singh T.N., Verma A.K., Singh V., Sahu A., "Slake durability study of shaly rock and its predictions", Environmental Geology 47 (2005) 246253.

24. Singh T.N., Sharma P.K., Khandelwal M., "Effect of pH on the physicomechanical properties of marble", Bulletin of Engineering Geology and the Environment 66(1) (2006) 81-87.

25. Sunil B.M., Nayak S., Shrihari S., "Effect of pH on the geotechnical properties of laterite", Engineering Geology 85 (2006) 197-203.

26. Yilma I., Karacan E., "Slake durability and its effect on the doline formation in the gypsum", Environmental Geology 47, (2005) 1010-1016. 